DOI: https://doi.org/10.32839/2304-5809/2019-9-73-15

UDC 378.147 .88

Bilonozhko Nataliia, Kyrylyuk Ol'ha

Taras Shevchenko National University of Kyiv

\title{
THE ROLE OF ESP PROJECTS WITHIN THE PROCESS OF INTERNATIONALIZATION OF THE UNIVERSITIES IN UKRAINE
}

Summary. The article outlines the learning initiatives of the countries with the English language High proficiency index. On the bases of this analysis the governments' actions that have led to a higher level of English proficiency in Germany, Hungary, Malaysia and Spain are highlighted. They include the establishment of Institute for quality development in education with the independent assessment; setting foreign language proficiency standards for primary and secondary schools; some projects on the development of the English language competences, the professional development of teachers, the introduction of bilingual instruction in classes; the optimization of the process of internationalization of higher education exchange of students and teachers. The laws and some important achievements in the field of teaching English in Ukraine are highlighted, namely: the results of teachers' participation in the international ESP project as a prerequisite of achieving excellence in the quality of ESP teaching.

Keywords: Internationalization, English Proficiency Index, ESP, learning initiatives, project.

Білоножко Н.Є., Кирилюк О.Л.

Київський національний університет імені Тараса Шевченка

\section{РОЛЬ ПРОЕКТІВ З АНГЛІЙСЬКОЇ МОВИ ЗА ПРОФЕСІЙНИМ СПРЯМУВАННЯМ У ПРОЦЕСІ ІНТЕРНАЦІОНАЛІЗАЦІЇ УНІВЕРСИТЕТІВ В УКРАЇНІ}

\begin{abstract}
Анотація. У статті представлено аналіз навчальних ініціатив з викладання англійської мови тих країн, які отримали високий рівень міжнародної індексації володіння англійською мовою. Проаналізовано рівень валідності ціеї індексації, яка проводиться щорічно швейцарською організацією Education First та представлено рейтинг України за 2013-2018 роки. Серед ініціатив та дій урядів, що сприяли підвищенню рівня володіння англійською мовою у Німеччині, Венгрії, Малазії та Іспанії, виокремлено такі як: створення Центру розвитку якості освіти, встановлення стандартів володіння іноземною мовою для початкових та середніх шкіл з незалежним оцінюванням результатів, впровадження проектів щодо розвитку англомовної мовленнєвої компетенції, професійного розвитку викладачів, впровадження двомовності інструкцій на заняттях, а також оптимізація процесу інтернаціоналізації вищої освіти шляхом обміну студентами та викладачами. Висвітлено прийняті закони та деякі важливі досягнення в галузі викладання англійської мови в Україні, а саме: представлено певні результати участі викладачів вищих шкіл у п’ятирічному міжнародному проекті з англійської мови за професійним спрямуванням. Окреслено мету, етапи цього проекту, особливості впровадження аналізу потреб студентів та підвищення рівня мотивації участі у таких проектах завдяки використанню рефлективного підходу під час тренінгів та дисемінацій. Наголошено на розумінні таких проектів, як платформи, яка дає можливість не тільки отримати нові знання, імплементувати сучасні підходи до ефективного оволодіння англійською мовою у навчальному процесі, але й поширити власний досвід та оцінити його крізь призму новітніх технологій. Зроблено висновок про важливу роль міжнародних проектів з викладання англійської мови взагалі та англійської мови за професійним спрямуванням зокрема у контексті процесу інтернаціоналізації вищої освіти.
\end{abstract}

Ключові слова: інтернаціоналізація, індекс знань, англійська мова за професійним спрямуванням, навчальні ініціативи, проект.

Gormulation of the problem. The fast growing phenomenon of the internationalization of the universities generates new demands to methods and approaches of the English for specific purposes teaching. Thus, the problem of improving the professional training of ESP teachers is very important because of the changes taking place in the field of higher education. It is especially relevant due to the fact that Ukraine occupies approximately the last position in the countries rating in EF English Proficiency Index. One of the ways of achieving higher results in teaching, getting acquainted with the new initiatives and progressive approaches in the educational process is the participation of ESP teachers in the international projects.

Identification of previously unsettled parts of the general problem. In spite of the reliable number of the research works in the mentioned field, the problem of the low index of Ukraine is out of the attention of the teachers and researchers.
The aim of the article. The article is aimed at conducting the analyses of the educational actions of the countries with High proficiency index, highlighting the implementation of the international ESP project "English for Universities" at Taras Shevchenko national university of Kyiv and presenting the experience in ESP teaching based on the developed initiatives for achieving excellence in ESP teaching in the context of higher education internationalization.

Methods. Scientific methods that have been used to obtain the aim are as follows: comparison and analyses of methodological sources, monitoring of the official sites of the world's most famous international ratings for institutions of higher education, generalization and conceptualization, synthesis of the positive experience of ESP teachers training within "English for universities" project, observation of the educational process. 
Analysis of recent research and publications. The problem of ESP teaching has been studied by T. Dudley-Evans, E.K. Nalan, J. Lee, J.N. Sandru, H. Day, M. Krzanowski, I. Soroca, K.E. Johnson, R. Bolitho, A. Waters, R. West, $\mathrm{K}$. Westerfield, as well as by the ukrainian researchers such as N.F. Borisko, Z.M. Korneva, L.G. Morska, N.K. Sklyarenko, I.A. Fedorova, I.B. Tarnopolsky, O.G. Polyakov, O.P. Bekonya, V.D. Borschovetska, A.I. Gordeeva, T.M. Korzh, G.A. Grinyuk and others.

As J. Harmer stated, language teaching, perhaps more than many other activities, reflects the time it takes place in $[6, p .9]$. These words point out at paying attention towards the latest researches and figures in order to be objective.

Results and discussion. Throughout the last decade a definite number of laws, initiatives, strategies dealing with FL teaching and learning have been developed and implemented. They include Laws of Ukraine "On Education", "About general secondary education", "On Higher Education", "Concept of the State Language Policy in Ukraine", the state educational standards "Primary General Education" and "Basic and Complete Secondary Education", "National Strategy for the Development of Education in Ukraine for the period from 2012 to 2021". S. Nikolaeva emphasizes that despite the laws adopted and such important achievements as an external independent evaluation of the students' learning outcomes, annual competitions for the best FL teacher and some other events, "the quality of secondary school's education in general and FL education, in particular, remains unsatisfactory" [11].

Having conducted in-depth baseline studies of universities in Ukraine, R. Bolitho and R. West presented their findings where they mentioned that standards of school leavers entering Ukrainian universities rarely reach CEFR B1 level. They strengthened it with the reference to a rating of Ukraine in EF English Proficiency Index, that has the great impact upon the ongoing research on the global role of English language education [2].

As far as this organization is concerned, one should mention, that EF, which stands for Education First, is a Swiss-based educational organization. Collaborating with the University of Cambridge Peking University and Harvard Graduate School of Education in language learning research, it provides an annual report on the national language proficiency of different countries that is based on test data from more than one million test takers who completed three different versions of the EF Standard English Test (EF SET) in the previous year [4].

The annual achievements of the countries are defined as Trending Down / Trending Up / Slight Decrease / Slight Increase. Ukraine is scored as trending up in 2017. But among the Proficiency Bands: High, Very High, Low, Moderate, Very Low
Ukraine is ranked as low proficiency. So in spite the fact that Ukraine experienced some progress, it still occupies the low position in ranking. The results of ranking of Ukraine in 2013-2018 presented by EF EPI are as follows:

It is noteworthy to mention the validity of this index. The authority of the EF English Proficiency Index recognizes that the validity of index has two sides of the medal. On the one hand the test-takers represented in this index are self-selected that can't be considered as a guarantee to be representative of the country as a whole. On the other hand, as it is mentioned on the official site of it, the open-access methods of Internet tests have proven effectiveness in gathering very large amounts of data about global English proficiency levels (Education First EPI, 2018). In Ukraine teachers need to inform students about this test, because only 1 person out of 10 test-takers knew about it.

The official site of EF EPI also suggests English learning initiatives that take place in different countries. It is natural to pay attention upon the initiatives of the countries that are marked with High Proficiency Index. They are Germany, Hungary, Malaysia and Moderate Proficiency Index - Spain.

Findings. So, this short analyses shows that there were some actions that led to the higher English language proficiency level that can be summed up as follows:

- Centre for Quality development in education (Institute) was established;

- FL standards were established for primary and secondary schools with the third-party assessment;

- Project on professional development of the English language skills as well as teaching skills training;

- Project on bilingualism of instructions with subsequent covering all the classes at schools;

- Internationalization of Higher education through students and faculty exchange.

We can conclude that one of the most effective European English language learning initiatives deals with the process of internationalization and some governmental initiatives that appeared to be effective. It is reasonable to consider the process of internationalization of Ukrainian universities in terms of mobility schemes as well as teacher training project "English for Universities", taking into consideration the experience of Taras Shevchenko national university of Kyiv as this university, for the first time in the history of Ukraine entered the subject rating "Modern Languages" according to The QS World University Rankings [14].

As the project has been lasted for 5 years the number of the participants is rather significant.

The English for Universities project has two goals:

1) to improve the quality of ESP teaching in HEI across Ukraine;

2) to promote higher quality English-Medium Instruction.

EF EPI 2017 RANKINGS of Ukraine

\begin{tabular}{|l|c|c|c|c|c|c|}
\hline \multicolumn{1}{|c|}{ Year } & $\mathbf{2 0 1 3}$ & $\mathbf{2 0 1 4}$ & $\mathbf{2 0 1 5}$ & $\mathbf{2 0 1 6}$ & $\mathbf{2 0 1 7}$ & $\mathbf{2 0 1 8}$ \\
\hline № of countries & 60 & 63 & 70 & 72 & 80 & 88 \\
\hline Place of Ukraine & 27 & 44 & 34 & 41 & 47 & 43 \\
\hline Proficiency Level & Moderate & Low & Moderate & Low & Low & Moderate \\
\hline
\end{tabular}


English learning initiatives in Europe after EF EPI

Table 2

\begin{tabular}{|c|c|c|c|}
\hline Country & $\begin{array}{l}\text { Proficiency } \\
\text { Index }\end{array}$ & \begin{tabular}{|c|} 
EF EPI \\
Score
\end{tabular} & English Learning Initiatives \\
\hline Germany & $\begin{array}{l}\text { High Proficiency } \\
\text { № } 10 \text { place out } \\
\text { of } 88 \text { countries }\end{array}$ & 63.74 & $\begin{array}{l}\text { Institute for quality development in education (2004) was } \\
\text { established, tasked with setting the math, reading, writing, and foreign } \\
\text { language standards for the country's primary and secondary schools. } \\
\text { The institute has been testing students across Germany since } 2006 \text {. } \\
\text { The third-party assessment by the OECD shows improvement in overall } \\
\text { educational outcomes. }\end{array}$ \\
\hline Hungary & $\begin{array}{c}\text { High Proficiency } \\
\text { № 21 of } \\
\text { 88 Countries }\end{array}$ & 59.51 & $\begin{array}{l}\text { Campus Hungary. From } 2012 \text { to } 2015 \text {, the Balassi Institute's Campus } \\
\text { Hungary program sought to internationalize Hungarian higher education } \\
\text { through student and faculty exchange. } \\
\text { It awarded more than } 20,000 \text { scholarships to Hungarian students who } \\
\text { wanted to study abroad, many in English-speaking countries, and } \\
\text { provided a web portal that international students could use to search for } \\
\text { foreign language university programs within Hungary. } \\
\text { Note: The Balassi initiative was unusual in that it encouraged travel in } \\
\text { both directions, sending more Hungarian students abroad, even as it tried } \\
\text { to internationalize the student body on Hungarian campuses. }\end{array}$ \\
\hline Malaysia & $\begin{array}{c}\text { High proficiency } \\
\text { № 22 of } \\
88 \text { Countries }\end{array}$ & 59.32 & $\begin{array}{l}\text { Professional Up-skilling of English Language Teachers (Pro-ELT), } \\
\text { funded by the Malaysian Ministry of Education, aims to develop the } \\
\text { English and teaching skills of Malaysian primary and secondary school } \\
\text { teachers. Since } 2012 \text {, the project has trained over } 15,000 \text { teachers across } \\
\text { all } 13 \text { states in Malaysia. The training itself consists either of weekly six- } \\
\text { hour sessions throughout the year, or an intensive, one-time training that } \\
\text { lasts four weeks. }\end{array}$ \\
\hline Spain & $\begin{array}{c}\text { Moderate } \\
\text { proficiency } \\
\text { № 32 of } \\
88 \text { countries }\end{array}$ & 55.85 & $\begin{array}{l}\text { Bilingual education project. This Education Ministry-sponsored } \\
\text { project aims to promote bilingualism by starting English classes from } \\
\text { a young age and implementing a whole-school approach. Over } 350 \text { public } \\
\text { primary schools in Madrid and another } 180 \text { private primary schools now } \\
\text { offer instruction in both English and Spanish. Teachers in these schools } \\
\text { are required to have a C1 level of English. }\end{array}$ \\
\hline
\end{tabular}

This study deals with the first goal of the project that has undergone some stages resulted in the significant outcomes. They are as follows:

- Baseline study; Observation lessons conducted by ESP Teachers of Kyiv university: The British Council observer - Richard West (2013);

- ESP teachers professional development included such courses as: ESP; ESP for newly qualified teachers; CiVELT 1: ESP essentials; CiVELT 2: Language of ESP ; CiVELT 1: ESP course and materials (2014-2018)

- Symposium 2017: reports of the Heads of The FL departments of 32 universities on the Project implementation.

- Symposium 2018 on excellence in internationalisation and ESP in Higher Education.

It should be stated that the events and their outcomes presented above is the vivid evidence of the Simon Williams' words that English for universities project is one of our flagship programs, achieving positive, transformational and sustainable change in the quality of teaching and learning of English in higher educational institutions [Foreword in 2].

Analyzing the process of teacher training it is vivid that one of the successful essentials that led to the effectiveness of Summer/Winter schools trainings is the reflective approach. As newly qualified teachers take everything for granted, experienced teachers are sometimes rather critical about new ideas. So, reflexing on their experience was beneficial for everybody. The experienced teachers suggested valuable ideas, techniques they use in different settings. But what is more important they subconsciously evaluated their work, reflected on the effectiveness of the activities in the classroom and so on. The same process of self-observation, self-evaluation was implemented during dissemination events.

According to Richard West, needs analysis is a key stage in the entire educational process from the determination of aims and objectives to the development of materials [16]. The participants of the first dissemination seminar were asked the questions whether it is important to conduct Needs analyses sessions with the students. $60 \%$ of the ESP teachers answered positively, 32\% supported this activity but asked for some clarification, 8\% rejected this activity. After practicing the Needs Analyses questionnaire in the classroom, in a year the newly adopted questionnaires were developed and used at the beginning of the study year with the second, third and fourth year students. The teachers concluded that:

- Needs analyses is a student-centered activity;

- Needs analyses questionnaire should be constantly evolved and designed;

-When a questionnaire is followed by interviewing the students it is more efficient than vice versa.

Needs Analyses questionnaire was worked out and adopted to the specifics of the English language teaching of different specialties. New ESP syllabi and teaching programs were adopted. Students' autonomy is being developed in terms of implementing new approaches, enhancing student centeredness and intrinsic motivation.

Conclusions. Internationalization of higher education is regarded as a means to improve the quality of education in general, enhancing the motivation of the English language learning in particular. The comparative analyses of the learning initiatives of different countries with high proficiency index showed that the English language 
teaching is a national strategy of these countries. It's of paramount importance for the Ukrainian educators, ESP teachers to participating in the international projects, improving their professional competence, making their contribution into the qualitative teaching process. Professional development of the ESP teachers is a way to enhance both a teacher and a learner, as well as the language proficiency for the sake of future successful business.

\section{References:}

1. Bilonozhko, N. (2018). English for specific purposes in the process of internationalization of Higher education in Ukraine. World science. Warsaw. 3 3(31), (5), 58-61.

2. Bolito, R., \& West, R. (2017). The internationalization of Ukrainian universities: the English language dimension. Kyiv. URL: https://www.teachingenglish.org.uk/sites/teacheng/files/Pub-UKRAINE-REPORT-H5-EN.pdf

3. Common European Framework of Reference for Languages: Learning, teaching, assessment (CEFR) (2001). Strasbourg, France: Council of Europe (Modern Languages Division). URL: https://rm.coe.int/1680459f97

4. Education First EPI. (2018). URL: https://www.efset.org/research/epi/

5. Egron-Polak, E. (2014). Internationalization of Higher Education: Growing expectations, fundamental values: IAU 4th Global Survey. International Association of Universities. URL: http://iau-aiu.net/sites/all/files/IAU-4thGLOBAL-SURVEY-EXECUTIVE-SUMMARY.pdf

6. Harmer Jeremy (2007). How to Teach English: Introduction to the Practice of English Language Teaching, Longman. Edinburgh.

7. Helms, R.M., Rumbley, L.E., \& Brajkovic L.G. (2015). Internationalizing Higher Education Worldwide: National Policies and Programs / American Council on Education, The Boston College Centre for International Higher Education. URL: http://www.acenet.edu/news-room/Documents/National-Policies-and-Programs-Part-1-Global.pdf

8. Kozievskaya, O. (2012). Strategies of internationalization of Higher education: international experience and Ukrainian perspectives. Vyscha shkola, (7), 30-39.

9. Law of Ukraine on Higher Education (2014). Ministry of Science and Education in Ukraine. URL: http://zakon3.rada.gov.ua/laws/show/1556-18

10. Lytovchenko, L., Ogienko, O., Sbruieva, A., \& Sotska, H. (2018). Teaching English for specific purposes to adult learners at university: methods that work. Advanced Education, 10, 69-75. URL: https://doi.org/10.20535/24108286.149741

11. Nikolaeva, S. (2017). Intercultural foreign language education in Ukraine in the context of the secondary school reform. Advanced Education, 8, 54-58. doi: 10.20535/2410-8286.111933

12. PICASA - Promoting Internationalization of HEIs in Eastern Neighbourhood Countries through Cultural and Structural Adaptations (2014). Graz, Austria. URL: http://picasa.ysu.am

13. Taras Shevchenko National University of Kyiv (2019). URL: http://www.univ.kiev.ua/ua

14. QS World University Rankings (2018). URL: https://www.topuniversities.com/qs-world-university-rankings

15. Ukaz Prezydenta Ukrainy (2013). Natsional'na stratehiiu rozvytku osvity $v$ Ukraini na period $z 2012$ do 2021 roku [National Strategy for the Development of Education in Ukraine for the period from 2012 to 2021 ]. URL: http://zakon2.rada.gov.ua/laws/show/344/2013

16. West, R. (1992). Teaching English for Specific Purposes - Unit 5: needs analysis approaches (a). Manchester: Centre for English Language Studies in Education, University of Manchester. 